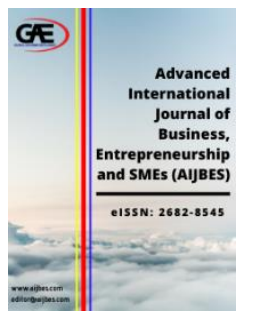

\author{
ADVANCED INTERNATIONAL JOURNAL OF \\ BUSINESS, ENTREPRENEURSHIP AND SMES \\ (AIJBES) \\ WWW.aijbes.com
}

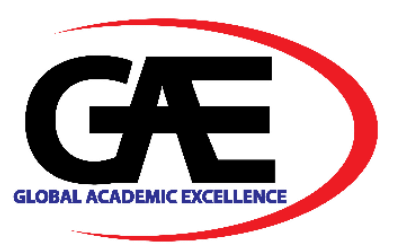

\title{
CEO SUCCESSION ORIGIN, TYPES AND ITS EFFECT ON PERFORMANCE IN MALAYSIA
} \author{
Mohd Zaini ${ }^{4}$, Azleen Shabrina Mohd Nor ${ }^{5}$ \\ 1 College of Business Administration, University of Bahrain, Bahrain \\ Email: wanmohammad@uobl.edu.bh \\ 2 Faculty of Management, Multimedia University, Malaysia \\ Email: hni0801@gmail.com \\ 3 College of Business Administration, University of Bahrain, Bahrain \\ Email: akumaraswamy@uob.edu.bh \\ $4 \quad$ Faculty of Management, Multimedia University, Malaysia \\ Email: rapiah@mmu.edu.my \\ 5 Faculty of Management, Multimedia University, Malaysia \\ Email: azleen.mohdnor@mmu.edu.my \\ Corresponding Author
}

Wan Masliza Wan Mohammad ${ }^{1 *}$, Siti Nurhani Sheikh Ahmad ${ }^{2}$, Sumathi Kumaraswamy ${ }^{3}$, Rapiah

\section{Article Info:}

\section{Article history:}

Received date: 15.10 .2020

Revised date: 22.10 .2020

Accepted date: 08.11.2020

Published date: 01.12.2020

\section{To cite this document:}

Mohammad, W. M. W., Ahmad, S. N. S., Kumaraswamy, S., Zaini, R. M., \& Nor, A. S. M. (2020). CEO Succession Origin, Types and Its Effect on Performance in Malaysia. Advanced International Journal of Business, Entrepreneurship and SMEs, 2 (6), 1022.

DOI: $10.35631 / \mathrm{AIJBES} .26002$.

This work is licensed under $\mathrm{CC}$ BY 4.0

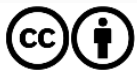

\section{Abstract:}

The purpose of this study is to investigate the effect of CEO succession origin (Internal versus External), types (Voluntary and Force) on firms' performance. The effect of CEO succession on firms' performance is investigated using a sample size of 80 firms which consists of 40 firms that had been identified from the list in Bursa Malaysia to have experienced CEO succession and 40 firms that do not experience CEO succession in the year 2014. All financial data and variables are gathered from annual reports and the Emerging Market Information System (EMIS). The findings of this study indicate that CEO origin has no effect on performance. However, the study found a positive association between forced CEO successions on performance. Our finding suggests forced change in the CEOs improve the performance over the lag two years' period. The appointment of new CEOs via force allows for comprehensive change in the strategy, business operations, and firm's future growth.

Keywords:

CEO, Succession, Corporate Governance, Performance 


\section{Introduction}

Malaysia has seen its fair share of CEO successions over the years. For instance, within the span of three years, Malaysia largest aircraft carrier, Malaysian Airlines has changed its CEO for four times and the nature of the departures of these two-outsider successors was vague as both announced their departure unexpectedly. Due to the vague nature of their departure, there is concern over its implication on Malaysian airlines performance as a national flight carrier.

Evidently conflicting findings in the literature were found on the effects of CEO succession on performance (Berns and Klarner, 2017; Zhang et al, 2016). For instance, some studies argue that CEO succession does not influence firm performance (Schepker et al, 2017; Choi et al, 2012; Chen \& Hambrick, 2012; Shen \& Cannella, 2002), whilst some studies argue that CEO succession results in decreasing firm performance (Pukthuanthong et al, 2017; Zhang et al, 2016; Boyne et al, 2011). In Malaysia there are limited studies conducted on CEO succession and some studies suggest that firms are more likely to change their CEOs when they are facing low performance (Ishak et. al, 2012).

Further, due to the different nature of CEO resignation, few studies have also shown that CEO succession plan is one of the majors concerned in a good transition between voluntary CEO resignation and the newly appointed CEO. Voluntary CEO resignation may positively improve performance as delegation of tasks was properly executed prior to their resignation. In fact, those firms with proper CEO succession plans have been found to perform better in comparison to those without CEO succession plans (Berns and Kalrner, 2017). Also, when succession planning was not in place, more costs were required due to third party involvement to find suitable CEO candidates. Under duress, limited time frame and strong pressure from certain parties, less qualified CEOs may be appointed to fulfil the needs of various parties (Khurana, 2000; Zhang, 2008; Chen and Hambrick, 2012).

The result of this research would be significant for academics and practitioners whereby it contributes to the growing literature on CEO succession and effective CEO practices in Malaysia. Malaysia is a diverse ethnic country with different religion, cultural and political beliefs. The roles of skilful and competent CEOs are important to improve the company's performance. Though, competent CEOs can be less effective when there is lack of CEO awareness on the divergence of ethnic, cultural and political factors. Therefore, we suggest future studies to delve on cultural and political issues to understand its implication on CEO effectiveness. Also, the outcome of this research would also help companies to understand the significant impact of CEO succession and measures to be taken by companies to ensure that future $\mathrm{CEO}$ succession planning is being done in the most strategic ways.

\section{Literature Review}

CEO succession is defined as the departure of a CEO from its official position, but not necessarily the firm because some CEO will take up another position such as the Chairman when they relinquish the CEO position (Barron et al, 2011). Research on CEO succession has long existed since the 1960s (Grusky, 1963; Gamson \& Scotch, 1964; Lambertides, 2009). The roles of CEO as a steward in achieving firms' goals are an essential factor of successful performing firms. Upper echelon theory has recognised the roles of CEO as the central factors in running, initiating and adapting to strategy changes in an organization (Zhang et al, 2016; Berns and Kalrner, 2017; Schepker et al, 2017). 
Volume 2 Issue 6 (December 2020) PP. 10-22 DOI 10.35631/AIJBES.26002

Past studies on the stock market reaction and firm performance show that the market reacts positively to the announcement of CEO succession (Rhim et al., 2006; Huson et al., 2004). On top of that, Bernard et al (2016) findings also indicate that CEO succession has a positive influence on firm performance which occurs five years after the succession event. In a short period of CEO succession, Ishak et al (2013) found that CEO succession improves post firm performance two years after the CEO succession.

Despite the important roles of CEO, past literature on CEO succession has raised suspicions about the benefit of CEO succession and some studies suggest improvement of the firm performance can only be observed when a capable CEO was appointed in comparison to its predecessor (Haveman, 1993; Chen and Hambrick, 2012). In fact, CEO succession is argued as a ritual rather than a sincere effort in improving corporate performance (Chen \& Hambrick, 2012; Pukthuanthong et al, 2017). In a few circumstances, the appointment of unqualified CEOs resulted in discontinued operations of firms due to CEOs inability to revive the company's financial condition (Barron et al., 2011). Since conflicting findings are found in previous, we posit the first hypothesis as follows:

$\mathrm{H}_{1}$ : CEO succession effects firm's post performance.

\section{CEO Successor Origin and Firms' Performance}

Past studies on CEO succession has identified CEO successor origin either internal or external appointment as an important factor influencing firm performance (Ishak et al, 2012; Lauterbach et al, 1999). CEO experience is measured based on CEOs ability to transform companies into a profitable company after their appointment. Nevertheless, the experience differs between those who develop their experience within the organisation and those externally appointed CEOs.

Previous studies suggest that external candidates are considered when their qualification is far more superior than internal candidate and has greater capabilities in managing the firms (Ishak et al, 2013; Lauterbach et al, 1999). Further, firms' may also opt for external candidates when there are no candidates available internally that fit the roles of the CEO (Parrino, 1997; Barron et al, 2011). In a technical industry like Malaysian Airlines CEO expertise is vital and finding a suitable and well experienced candidate is a daunting task. Also, announcement of CEO succession may negatively affect the stock market if the financial situation of a firm is in a dire state. Instead, news on the appointment of well qualified CEOs may improve market confidence and send positive signals to the market (Finkelstein \& Hambrick, 1996; Parrino, 1997; Shen \& Cannella, 2002; Lambertides, 2009).

Chen and Hambrick (2012) on their research on CEO replacement in turnaround situations, conclude that firms that hire an outsider as CEO have a better chance of improving firm performance when the firm is said to be underperforming. In fact, Khurana \& Nohria (2000) find that no improvement is observed in the performance of the firms that internally appointed their CEO as compared to external appointed CEO post succession events.

Conclusively, the effectiveness of internal CEOs over external success varies between firms, some appoints internal candidates for the CEO position to ensure that firms' current strategy is continued, and some prefer external CEOs due to their technical expertise (Parrino, 1997; Berns $\&$ Klarner, 2017). Further, change in the top management may negatively influence employee's motivation when outside CEOs are appointed (Shen \& Cannella, 2002). Since conflicting 
Volume 2 Issue 6 (December 2020) PP. 10-22 DOI 10.35631/AIJBES.26002

findings are found on the research on CEO successor origin and performance, this study posits the second hypothesis as follows:

$\mathrm{H}_{2}$ : Internal and external CEO succession types affect firms' post performance.

\section{Succession Type and Firm Performance}

Aside from CEO successor origin, there is also a difference between the performance of the CEO when the resignation is either voluntary or forced. Lambertides (2009) on the study of CEO vacancy and long run economic effects reports that voluntary CEO succession as a result of retirement have a significant positive relationship with post firm performance. Plausible explanation is due to its planned transition of the CEO, and firm's ability to understand the effect of CEO succession on market reactions. It is argued that planned transition will allow the firms to adjust with the new management leadership and this positively influences post firms' performance. Whereas, when CEOs depart, the negative effects of the change in the new management may reduce the firms' focus on their strategy and post-performance (Khurana \& Nohria, 2000; Huson et al, 2004). Further, forced succession of the CEO may be linked to negative activities such as earnings management, fraud, political influence and also CEO incapability to manage firms' internal conflicts.

Despite the consequences of forced succession, effective management leadership after forced succession also illustrate firms' ability to embrace new ideas and strategic goals. Also, by appointing more qualified and experienced CEOs after forced succession, firms' can effectively implement a positive work culture, strategic goals and direction. Amidst the ongoing debate on the effect of forced succession on performance, recent study findings found that both voluntary and forced CEO succession is not significantly related to post firm performance (Bernard et al, 2016; Ishak et al., 2013). Due to the conflicting findings, we aim to investigate CEO resignation either forced or voluntary on firms' performance.

Hence, the third hypothesis is as follows:

H3: CEO succession types effects firms' performance.

\section{Research Model and Analysis}

The research model is as follows:

$$
\begin{aligned}
& \text { PERFORMANCE }=\alpha 0+\beta 1 \text { TURNOVER }+\beta 2 \text { ORIGIN }+\beta 3 \text { TYPE }+\beta 4 L E V+ \\
& \beta 5 \text { FIRMSZ }+\beta 6 \text { ROA } A_{t-1}+\beta 7 \text { ROE } \\
& t-1+\beta 8 \text { ROS }_{t-1}+\beta 9 \text { CURRENT }+e
\end{aligned}
$$

We adopt Panel Corrected Standard Errors (PCSE) to correct for heteroscedasticity and autocorrelation issues with the data. The regression model is run using Stata software. The explanation of dependent, independent and control variable is as follows:

$\begin{array}{ll}\alpha 0 & \text { Intercept } \\ \text { TURNOVER } & \text { CEO turnover (1 or 0) } \\ \text { ORIGIN } & \text { Origin of successor (Internal or External) } \\ \text { TYPE } & \text { Turnover Type (Voluntary or Forced) } \\ L E V & \text { The debt level of the firm } \\ \text { FIRMSZ } & \text { Firm size } \\ \text { ght } \odot \text { GLOBALACADEMIC EXCELLENCE } & (M) S D N B H D \text { - All rights reserved }\end{array}$


$R O A_{t-1}$

$R O E_{t-1}$

$R O S_{t-1}$

CURRENT

$e$

\section{Research Design}

This study incorporates quantitative research design that investigate the correlation between firm's performance and CEOs turnover. In designing this, we control for CEOs turnover either through internal or external appointments. Further we also control whether the resignation is forced or voluntary. This allows us to segregate our observation on the effect of different types of CEOs turnover on performance. Other than that, we control firms leverage, size, profitability and liquidity.

\section{Research Instruments}

Table 1 presents the list of variables and its measurement. The dependent variables used to measure firm performance are ROA, ROE and ROS. We selected the CEO succession in 2014 based on the announcement made in Bursa Malaysia. CEO succession (TURNOVER) is indicated as 1 if the firm had experienced CEO succession or 0 otherwise (Ishak et al., 2013). Similarly based on Bursa Malaysia announcement, the CEO origin (ORIGIN) is indicated as 1 if their CEO is from within the firm or 0 otherwise. Following Georgakakis and Ruigrok (2017), a successor from within the firm is known as an insider/internal CEO while a successor, other than within the firm is known as an outsider/external CEO successor. Similar to Schepker et al. (2017) research, CEO succession type (TYPE) is indicated as 1 if the firm CEO succession is voluntary or 0 otherwise.

There are six control variables used for this study. Firm size is measured using the natural logarithm of total assets collected from the annual report of the firms. Past studies have considered firm size to control for large firms' reaction and their ability to change their management (Pi and Lowe, 2011). Firm's leverage ratio is collected from Emerging Market Information System (EMIS) database to measure the percentage of total liabilities over total assets, and control for firm's financial risk (Zhang et al, 2016; Chen and Hambrick, 2012). Three control variables $\left(\mathrm{ROA}_{\mathrm{t}-1}, \mathrm{ROE}_{\mathrm{t}-1}, \mathrm{ROS}_{\mathrm{t}-1}\right)$ are used to control for companies past performances. Past performances are important indicators to gauge $\mathrm{CEO}$ ability to improve firms' performance. To avoid biases in firms' performance, past firm performance provides better interpretation over post performance measures after CEO appointment (Zhang et al, 2016, and Boyne at al., 2011). We used past performance measures in 2013 one year prior to CEO succession. Finally, to control for firms' liabilities we use current ratio (Chen and Hambrick, 2012).

Table 1. List of Variables and Measurement of Variables

\begin{tabular}{lll}
\hline Variables & Acronym & Operationalization \\
\hline $\begin{array}{l}\text { Dependent variables } \\
\text { Return on Assets }\end{array}$ & ROA & $\begin{array}{l}\text { Percentage of net income to total assets } \\
\text { Return on Equity }\end{array}$ \\
$\begin{array}{ll}\text { ROE } \\
\text { Return on Sales }\end{array}$ & ROS & $\begin{array}{l}\text { equity } \\
\text { Percentage of net income to net sales }\end{array}$
\end{tabular}


Volume 2 Issue 6 (December 2020) PP. 10-22 DOI 10.35631/AIJBES.26002

CEO Succession

CEO Origin

Succession Type

Control Variables

Firm Size

Leverage

Return on Asset prior to succession

Return on Equity prior to $\mathrm{ROE}_{\mathrm{t}-1}$ succession

Return on Sales prior to $\operatorname{ROS}_{\mathrm{t}-1}$ succession

Current Ratio
FIRMSZ

LEV

TURNOVER

ORIGIN

TYPE

$\mathrm{ROA}_{\mathrm{t}-1}$

CURRENT
1 if the firm has CEO succession and 0 if otherwise

1 if the firm CEO origin is outsider and 0 if otherwise

1 if the firm CEO succession type is voluntary and 0 if otherwise

Natural log of total assets

Percentage of total liabilities to total assets

Percentage of net income to total assets prior to succession

Percentage of net income to shareholder's equity prior to succession

Percentage of net income to net sales prior to succession

Liquidity ratio measure by current assets over current liabilities

\section{Population and Sample Selection}

The sample of the study includes 80 companies except for financial institutions listed in the main market of Bursa Malaysia. This study used balanced observation of 40 companies with CEO succession and another 40 companies within the same industries and size act as control firms. A match-pair process is adopted in the control group, with similar financial year end, size and sector to allow comparison to be made between the firms selected in this study. The CEO succession year is 2014, 7 years after the global financial crisis in 2007-2008, and considered as the year of financial stability in Malaysia with growth ranging from 4.5 to $5.5 \%$. Following Ishak et al. (2013), the dependent variable, which is the performance ratios are collected in 2016, which is 2 years after CEO succession to adequately measure CEO effectiveness. In their study, Ishak et al. (2013) suggests that post performance measures improve after 2 years of CEO appointment in Malaysia. The 2 years is also based on the average number of years of contract renewal for CEOs appointments in Malaysia.

All variables used for this study are gathered from annual reports of the companies and Emerging Market Information System (EMIS) database. The CEO succession variables are collected from annual reports announcement on Bursa Malaysia and the financial ratios are collected from EMIS.

\section{Results and Findings of The Study}

\section{Descriptive Result}

Table 2.0 depicts the descriptive statistics for all variables. The average percentage of return on asset (ROA) is $-0.956 \%$. The minimum and maximum percentage of ROA is $-67.67 \%$ and $39.76 \%$ respectively. This reflects the diversity of the sample where some poor performance firms' ROA is linked to firms experiencing CEO succession. Previous studies suggest evidence of poor performance as one of the factors for CEO succession and most firms selected in this study have negative average ROA (Finkelstein \& Hambrick, 1996; Parrino, 1997; Shen \& Cannella, 2002; Lambertides, 2009). 
Volume 2 Issue 6 (December 2020) PP. 10-22 DOI 10.35631/AIJBES.26002

Table 2. Descriptive Statistics

\begin{tabular}{lcccc}
\hline Variable & Mean & Std. Dev. & Min & Max \\
\hline ROA & -0.956 & 18.035 & -67.670 & 39.760 \\
ROE & -9.809 & 58.488 & -246.700 & 73.550 \\
ROS & 2.113 & 39.634 & -88.000 & 173.190 \\
CEOTRN & 0.5 & 0.5 & 0 & 1 \\
CEOORG & 0.45 & 0.503 & -1 & 1 \\
TURNTP & 0.625 & 0.490 & -1 & 1 \\
ROA(t-1) & -15.662 & 88.796 & -554.38 & 11.34 \\
ROE(t-1) & -4.231 & 93.637 & -551.02 & 148.29 \\
ROS(t-1) & -13.828 & 69.239 & -407.45 & 23.88 \\
FRMSZ & 13.383 & 2.259 & 8.907 & 20.938 \\
LEV & 3.074 & 6.557 & -1.69 & 42.22 \\
CURRENT & 1.827 & 1.295 & 0.04 & 6.09 \\
\hline
\end{tabular}

Similarly, negative ROE is also observed with an average of $-9.809 \%$. The range of minimum and maximum percentage of ROE is from $-246.7 \%$ to $73.55 \%$. The minimum ROE suggests significant losses of the firms which justify for CEO succession either voluntary or forced. The final performance measure, ROS, has an average percentage of $2.113 \%$ whilst the minimum percentage is $-88.00 \%$ and the maximum percentage is $173.19 \%$. The large spread of ROS allows this study to further understand the effect of CEO succession on ROS.

The mean for CEO succession, is 0.5 , followed by CEO origin whose mean statistics is 0.45 and CEO succession type mean statistics is 0.625 . The average percentage of $\mathrm{ROA}_{\mathrm{t}-1}$ is $-15.66 \%$ whilst the maximum percentage is $11.34 \%$ and the minimum percentage is $-554.38 \%$. The average percentage of $\mathrm{ROE}_{\mathrm{t}-1}$ is $-4.23 \%$, whilst the maximum and minimum percentage both stand at $148.29 \%$ and $-551.02 \%$ respectively. As explained earlier, previous studies suggest lower performance as the main justification of CEO successions with a minimum percentage of $-551.02 \%$, highlight the dire states of the firms. We also observed discouraging trends in return on sales, average $\mathrm{ROS}_{\mathrm{t}-1}$ stands at $-13.82 \%$ with maximum percentage of $23.88 \%$ and minimum percentage of $-407.45 \%$.

Table 3 shows the distribution of internal versus external CEO succession. From the table it can be summarized that $55 \%$ percent of the CEO were internally appointed and $45 \%$ were externally appointed CEO. The internal appointed CEO suggests firm's tendency to continue with firms' business strategy and avoid negative publicity from CEO resignation. Nonetheless, $45 \%$ of the firms appoint external CEOs indicating shareholders' interest to urgently change the firm's business structure and gain shareholders' interest and trust. Further, based on the sample of this study, most CEOs resign voluntarily to avoid negative news and reaction from the stock market. Nonetheless forced CEO succession accounts for 37\% of CEO succession and signals firms' effort in gaining the trust of shareholders and improving the firm's overall strategy. 
Volume 2 Issue 6 (December 2020) PP. 10-22

DOI 10.35631/AIJBES.26002

Table 3. Distribution of CEO Succession Observation based on Insider, Outsider, Voluntary and Forced CEO Succession

\begin{tabular}{lcc}
\hline & \multicolumn{2}{c}{ CEO Succession } \\
& No. of Observation & Percentage (\%) \\
\hline Internal & 22 of 40 & 55 \\
External & 18 of 40 & 45 \\
Voluntary & 25 of 40 & 63 \\
Forced & 15 of 40 & 37 \\
\hline
\end{tabular}

Table 4 presents the distribution of performance between firms experiencing CEO succession and those without CEO succession. As predicted, average performance of the firms experiencing CEO succession is weak in comparison to those without CEO succession (Average ROA and ROE are only -0.96 percent and -9.81 percent respectively). Since the control firms of this study are selected based on similar financial year end, size and sector, most firms without CEO succession are also observed to experience moderate or low average ROE, ROA and ROS respectively.

Table 4. Distribution of Performance based on CEO succession

\begin{tabular}{lcc}
\hline & \multicolumn{2}{c}{ Performance Ratios } \\
\hline & CEO Succession & Without CEO Succession \\
\hline Average ROA & -0.96 & 3.23 \\
Average ROE & -9.81 & 30.13 \\
Average ROS & 2.11 & 2.78 \\
\hline
\end{tabular}

\section{Pearson Correlation Results}

Table 5 depicts the Pearson correlation result. Our observation indicates no issue of multicollinearity exists. Further, there is a significant positive relationship between return on equity (ROE), firm size (FRMSZ) and current ratio at $1 \%$ significance level. It can be interpreted as most firms with good performance are linked to firms' size and their liquidity level.

Also, significant positive relationship at 1 percent level between return on assets lag one year (ROA t-1) and return on sales lag one year (ROS t-1) with coefficient value of 0.961 at 1 percent significance level is observed. Further, there is also a 5\% significant positive relationship between return on assets lag one year (ROA t-1) and leverage (LEV). In fact, a significant negative relationship at $1 \%$ between return on equity lag one year (ROE t-1) and firm size (FRMSZ) is also observed. It can be summarized that past performance has an effect on future performance.

Further, as shown in Table 5, a positive relationship at 5\% significance level between return on sales lag one year (ROS t-1) and leverage (LEV) is also found. Finally, there is a positive relationship at $1 \%$ significance level between firm size (FRMSZ) and current ratio (CURRENT). It indicates association between firms' size and liquidity ratio. 
Volume 2 Issue 6 (December 2020) PP. 10-22 DOI 10.35631/AIJBES.26002

Table 5. Pearson Correlation Matrix

\begin{tabular}{lllllllllll}
\hline & ROA & ROE & ROS & $\begin{array}{l}\text { CEOT } \\
\text { R }\end{array}$ & $\begin{array}{l}\text { ROA } \\
(\mathrm{t}-1)\end{array}$ & $\begin{array}{l}\text { ROE } \\
(\mathrm{t}-1)\end{array}$ & $\begin{array}{l}\text { ROS } \\
(\mathrm{t}-1)\end{array}$ & $\begin{array}{l}\text { FRMS } \\
\text { Z }\end{array}$ & $\begin{array}{l}\text { LEV } \\
\text { ENT }\end{array}$ \\
\hline ROA & 1.000 & & & & & & & & & \\
ROE & 0.122 & 1.000 & & & & & & & & \\
& 0.279 & & & & & & & & & \\
ROS & $0.579^{*}$ & 0.082 & 1.000 & & & & & & & \\
& 0.00 & 0.471 & & & & & & & & \\
CEOTR & -0.156 & -0.152 & -0.010 & 1.000 & & & & & & \\
& 0.167 & 0.178 & 0.931 & & & & & & & \\
ROA & -0.140 & 0.010 & -0.040 & -0.159 & 1.000 & & & & & \\
(t-1) & 0.214 & 0.930 & 0.726 & 0.158 & & & & & & \\
ROE & -0.004 & -0.050 & -0.004 & -0.71 & -0.123 & 1.000 & & & & \\
$(\mathrm{t}-1)$ & 0.969 & 0.661 & 0.969 & 0.354 & 0.278 & & & & \\
ROS & -0.020 & 0.024 & -0.008 & -0.215 & $0.961^{*}$ & -0.109 & 1.000 & & & \\
(t-1) & 0.863 & 0.834 & 0.943 & 0.056 & 0.000 & 0.335 & & & & \\
FRMSZ & 0.009 & $0.432^{*}$ & 0.018 & 0.026 & 0.044 & - & 0.046 & 1.000 & & \\
& 0.940 & 0.000 & 0.872 & 0.820 & 0.697 & $0.799^{*}$ & 0.684 & & & \\
& & & & & & 0.000 & & & & \\
LEV & 0.061 & 0.003 & 0.153 & 0.103 & $0.268^{*}$ & 0.018 & $0.347^{*}$ & 0.044 & 1.000 & \\
& 0.591 & 0.977 & 0.175 & 0.363 & 0.016 & 0.877 & 0.002 & 0.698 & & \\
CURR & -0.036 & $0883^{*}$ & -0.001 & -0.190 & 0.025 & -0.097 & 0.037 & $0.513^{*}$ & -0.053 & 1.000 \\
ENT & 0.752 & 0.000 & 0.994 & 0.91 & 0.824 & 0.393 & 0.747 & 0.000 & 0.643 & \\
\hline
\end{tabular}

*Statistically significant at $5 \%$ (2-tailed)

\section{Analysis of Results}

Model 1 (Table 6) presents the results of ROA with three independent variables which are CEO succession, CEO origin and succession type. All three independent variables show insignificant relationship with ROA. Therefore, we failed to support hypothesis 1 of this study $H_{1}: C E O$ succession effects firm's post performance when performance is measured by ROA.

Table 6. MODEL 1 CEO Succession and Firm's Post Performance

\begin{tabular}{lllll}
\hline $\begin{array}{l}\text { Dependent Variable }- \\
\text { ROA }\end{array}$ & Coef. & S.E & $\mathrm{Z}$ & $\mathrm{P}>|\mathrm{z}|$ \\
\hline CEOTURN & 0.5978 & 0.4649 & 1.28 & 0.2027 \\
CEOORG & -0.1342 & 0.1777 & -0.75 & 0.4527 \\
TURNTP & -0.3090 & 0.1941 & -1.59 & 0.1159 \\
ROA(t-1) & 0.7371 & 0.4621 & 1.59 & 0.1152 \\
ROE(t-1) & 0.7870 & 0.3462 & 2.27 & $0.0261^{*}$ \\
ROS(t-1) & -0.9513 & 0.4647 & -2.04 & $0.0444^{*}$ \\
FRMSZ & 3.6633 & 4.4756 & 0.8185 & 0.4158 \\
LEV & 1.1235 & 0.5454 & 2.05 & $0.0431^{*}$ \\
CURRENT & 0.3244 & 0.4795 & 0.68 & 0.5009 \\
CONS & -4.1480 & 3.7593 & -1.10 & 0.2736 \\
\hline
\end{tabular}

CEOTURN: Firm experiencing succession, CEOORG: Origin of CEO, TURNTP: CEO succession type, ROA(t1): return on assets prior to succession, $\operatorname{ROE}(\mathrm{t}-1)$ : return on equity prior to succession, $\operatorname{ROS}(\mathrm{t}-1)$ : return on sales 
Volume 2 Issue 6 (December 2020) PP. 10-22 DOI 10.35631/AIJBES.26002

prior to succession, FRMSZ : firm size, LEV: leverage, CURRENT RATIO: Current ratio of the firm.* P-value is significant when $\mathrm{p}<0.1$.

Model 2 (Table 7) shows negative significant results of ROE and succession types at 10 percent significance level. Therefore, our study supports $\mathrm{H}_{3} \mathrm{CEO}$ succession types that affect firms' firm performance when performance is measured by ROE. This result shows that succession type influences a firm's performance. It is observed that when succession is forced the change in management improves firms' performance. This allows for drastic change on the management structure and process of an organization.

Lastly in Model 3 (Table 8), ROS shows negative significant results with succession types at 10 percent significance level. Therefore, again similar to Model 2, our study supports $\mathrm{H}_{3}$ : $\mathrm{CEO}$ succession types affect firms' performance when performance is measured by ROS.

Nonetheless we failed to support our second hypothesis, $\mathrm{H}_{2}$ Internal and external CEO succession type's effects firms' post performance. Factors that may contribute to this result may be due to the fact that firm's performances are the results of CEO expertise instead of their origin either internal or external appointed CEOs. In a situation where no qualified CEOs available internally the results may differ as certain industries may require certain skills, experience, technological change in the business operation whereby no internally appointed candidates fit the roles (Parrino, 1997; Berns \& Klarner, 2017).

Table 7. MODEL 2 CEO Succession and Firm's Post Performance

\begin{tabular}{lllll}
\hline $\begin{array}{l}\text { Dependent Variable }- \\
\text { ROE }\end{array}$ & Coef. & S.E & $\mathrm{Z}$ & $\mathrm{P}>|\mathrm{z}|$ \\
\hline CEOTURN & 0.8093 & 0.5388 & 1.50 & 0.1376 \\
CEOORG & -0.2126 & 0.2060 & -1.03 & 0.3056 \\
TURNTP & -0.3860 & 0.2250 & -1.71 & $0.0907^{*}$ \\
ROA(t-1) & 0.2912 & 0.5357 & 0.54 & 0.5884 \\
ROE(t-1) & 0.7362 & 0.4013 & 1.83 & $0.0708^{*}$ \\
ROS(t-1) & -0.5489 & 0.5387 & -1.02 & 0.3117 \\
FRMSZ & 11.12 & 5.1876 & 2.14 & $0.0355^{*}$ \\
LEV & 0.6253 & 0.6322 & 0.98 & 0.3260 \\
CURRENT & 0.6731 & 0.5558 & 1.21 & 0.2299 \\
CONS & -10.3510 & 4.3574 & -2.37 & 0.0203 \\
\hline
\end{tabular}

EOTURN: Firm experiencing succession, CEOORG: Origin of CEO, TURNTP: CEO succession type, ROA(t-1): return on assets prior to succession, $\operatorname{ROE}(\mathrm{t}-1)$ : return on equity prior to succession, $\mathrm{ROS}(\mathrm{t}-1)$ : return on sales prior to succession, FRMSZ: firm size, LEV: leverage, CURRENT RATIO: Current ratio of the firm. * P-value is significant at when $\mathrm{p}<0.1$ 
Volume 2 Issue 6 (December 2020) PP. 10-22 DOI 10.35631/AIJBES.26002

Table 8. MODEL 3 CEO Succession and Firm's Post Performance

\begin{tabular}{lllll}
\hline Dependent Variable - ROS & Coef. & S.E & $\mathrm{z}$ & $\mathrm{P}>|\mathrm{z}|$ \\
\hline CEOTURN & 0.7754 & 0.5242 & 1.47 & 0.1436 \\
CEOORG & -0.2125 & 0.2004 & -1.06 & 0.2926 \\
TURNTP & -0.3806 & 0.2189 & -1.73 & $0.0865^{*}$ \\
ROA(t-1) & 0.3256 & 0.5212 & 0.62 & 0.5341 \\
ROE(t-1) & 0.9140 & 0.3905 & 2.34 & $0.0221^{*}$ \\
ROS(t-1) & -0.7364 & 0.5241 & -1.40 & 0.1644 \\
FRMSZ & 5.4858 & 5.0473 & 1.08 & 0.2802 \\
LEV & 1.455 & 0.6150 & 2.36 & $0.0207^{*}$ \\
CURRENT & 0.5479 & 0.5407 & 1.01 & 0.3144 \\
CONS & -6.0154 & 4.2395 & -1.41 & 0.1604 \\
\hline
\end{tabular}

CEOTURN: Firm experiencing succession, CEOORG: Origin of CEO, TURNTP: CEO succession type, ROA(t1): return on assets prior to succession, $\operatorname{ROE}(\mathrm{t}-1)$ : return on equity prior to succession, $\operatorname{ROS}(\mathrm{t}-1):$ return on sales prior to succession, FRMSZ : firm size, LEV: leverage, CURRENT RATIO: Current ratio of the firm.* P-value is significant at when $\mathrm{p}<0.1$

\section{Conclusion and Discussion}

The objective of this research is to investigate the effect of CEO succession on firms' performance. Circumstances surrounding the nature of appointment either internal (CEO Insider) or external (CEO Outsider) is an interesting avenue for research due to major differences between different types of CEOs appointment. In an environment when there is a variety culture and political influence, appointment of external CEOs, to some extent may represent an existence of good governance particularly in government linked companies. Malaysian Airlines for instance are known to appoint few controversial external CEOs publicly during the period of their financial struggles. Nonetheless, appointment of external CEOs may risk diverging into the need of trade unions and stakeholders. Some argued that internal CEOs are argued to perform better due to their ability to leverage their goals with the right business culture and operation ethics. Nonetheless, for change or reform to exist, the roles of CEOs are imperative for a comprehensive change in the operations and business culture of the firms.

Therefore, due to the different nature of CEOs appointment and resignation, this research aims to explore more on CEOs appointment either internal or external, voluntary versus forced and its influence over firms' performance. Based on the sample of 80 firms, our finding indicates that forced CEO turnover improves performance. One plausible explanation may be due to change in the work culture, business strategy and firm's objective after forced CEO turnover. Newly appointed CEO after forced CEO succession, may have the support and trust of shareholders that facilitates new management commitment in delivering better financial results.

Also, the effects of CEO technical expertise and shareholders' activism in reviving the firm's performance, is the core factor ensuring firms' ability to remain competitive in the market. Even though our study fails to associate any association between CEO origin either internal or external on firms' performance, we believe by segregating the study into technical versus nonCopyright $\odot$ GLOBAL ACADEMIC EXCELLENCE (M) SDN BHD - All rights reserved 
Volume 2 Issue 6 (December 2020) PP. 10-22 DOI 10.35631/AIJBES.26002

technical industry may improve future study's findings. In a technical industry where CEOs expertise is lacking, the appointment of externally appointed CEOs may improve the findings of future studies. Aside from the technical expertise of the CEOs, future studies can also delve into cultural, ethnicity and political factors that may influence CEOs ability to improve firm's performance.

Our study failed to support $\mathrm{H}_{1}$ : CEO succession effects firm's post performance and $\mathrm{H}_{2}$ Internal and external CEO succession type's effects firms' post performance. The findings can be generally summarized that, the performance of a company depend on synergize efforts of a team, CEO expertise is essential but it's irrelevant whether the appointment is made internally or externally. The focus should be to develop a team that meet the needs of various stakeholders, and independent from external interference.

Our findings have several implications towards the growth in the studies surrounding CEOs succession. Firstly, CEOs succession requires a thorough transition period to allow for greater acceptance by the management in the leadership change. Secondly, shareholders' activism is essential to allow for immediate CEOs succession to proceed. Since our findings indicate positive association between CEOs' forced turnover and firms' performance, the roles of the new appointed CEOs lie in their ability to not solely improve financial figures but also the overall business strategy and staff morale.

\section{References}

Barron, J. M., Chulkov, D. V., \& Waddell, G. R. (2011) 'Top Management Team Turnover, CEO Succession Type, and Strategic Change', Journal of Business Research, Vol. 64, No.8, pp. 904-910.

Bernard, Y., Godard, L., \& Zouaoui, M. (2016) 'The Effect OF CEOs' Turnover on the Corporate Sustainability Performance of French Firms', Journal of Business Ethics, Vol.150, No.4,pp.1049-1069.

BigBoyne, G. A., James, O., John, P., \& Petrovsky, N. (2011)' Top Management Turnover and Organizational Performance: A Test of a Contigency Model. Public Administration Review', Vol.71, No.4,pp. 572-581.

Chen, G., \& Hambrick, D. C. (2012) 'CEO Replacement in Turnaround Situations: Executive (Mis)Fit and Its Performance Implications', Organization Science, Vol.23, No.1,pp 225-243.

Choi, J.-S., Kwak, Y.-M., \& Choe, C. (2012) 'Earnings Management Surrounding CEO Turnover: Evidence from Korea', Journal of Accounting, Finance and Business Studies, Vol.50, No.1,pp. 25-55.

Finkelstein, S., \& Hambrick, D. C. (1996) 'Strategic Leadership: Top Executives and Their Effects on Organizations', Australian Journal of Management, Vol.2, No.2, pp. 221224.

Gamson, W. A., \& Scotch, N. A. (1964) 'Scapegoating in Baseball. American Journal of Sociology', Vol.70, No.1, pp 69-72.

Georgakakis, D., \& Ruigrok, W. (2017) 'CEO Succession Origin and Firm Performance: A Multilevel Study. Journal of Management Studies', Vol.54, No.1, pp.58-87.

Grusky, O. (1963) 'Managerial Succession and Organizational Effectiveness. American Journal of Sociology', Vol.69, No.1,pp.21-31.

Haveman, H. A. (1993) 'Ghost of Managers Past: Managerial Succession and Organizational Mortality. The Academy of Management Journal', Vol.36,No.4,pp. 864-881. 
Volume 2 Issue 6 (December 2020) PP. 10-22 DOI 10.35631/AIJBES.26002

Huson, M. R., Malatesta, P. H., \& Parrino, R. (2004) 'Managerial Succession and Firm Performance. Journal of Financial Economics', Vol. 74, No. 2, pp.237-275.

Ishak, R., \& Ismail, K. N. (2012) 'Determinants of Internal vs External CEO Succession in Malaysian Public Listed Companies. Asian Academy of Management Journal', Vol.17, No.2,pp. 79-96.

Ishak, R., Ismail, K. N., \& Abdullah, S. N. (2013) 'CEO Succession and Firm Performance: Evidence from Publicly Listed Malaysian Firms', Asian Academy of Management Journal of Accounting and Finance, Vol. 9, No. 2, pp.29-48.

Khurana, R., \& Nohria, N. (2000) 'The Performance Consequences of CEO Turnover. Working Paper, MIT Sloan School of Management, Boston.

Lambertides, N. (2009) 'Sudden CEO Vacancy and the Long-run Economic Consequences. Managerial Finance', Vol.35, No.7,pp. 645-661.

Lauterbach, B., Vu, J., \& Weisberg, J. (1999) 'Internal vs. External Succesion and Their Effect on Firm Performance', Human Relations, Vol.52,No.12,pp. 1485-1504.

Parrino, R. (1997) 'CEO Turnover and Outside Succession: A cross-sectional Analysis', Journal of Financial Economics, Vol.46, No.2,pp. 165-197.

Pi, L., \& Lowe, J. (2011) 'Can a Powerful CEO avoid Involuntary Replacement? An Empirical Study from China', Asia Pacific Journal Management, Vol. 28, No.4, pp.775-805.

Pukthuanthong, K., Ullah, S., Walker, T. J., \& Wu, X. (2017) 'Timely vs. Delayed CEO Turnover. Information Systematic Frontier', Vol.19,No. 3, pp. 469-479.

Rhim, J. C., Peluchette, J. V., \& Song, I. (2006)', Stock MArket Reaction and Firm Performance Surrounding CEO Succession: Antecedents of Succession and Successor Origin', Mid-American Journal of Business, Vol.21, No.1, pp. 21-30.

Schepker, D. J., Kim, Y., Patel, P. C., Thatcher, S. M., \& Campion, M. C. (2017)' CEO Succession, Strategic Change and Post Succession Performance: A Meta Analysis', The Leadership Quaterly, Vol.28,No. 6,pp. 701-720.

Shen, W., \& Cannella, A. A. (2002)'Revisiting the Performance Consequences of CEO Succession: The Impacts of Successor Type, Post Succession Senior Executive Turnover and Departing CEO Tenure', The Academy of Management Journal, Vol.45, No.4, pp. 717-733.

Tan, C.K., (2017) 'Company in focus: Malaysia Airlines loses another CEO as its malaise deepens, https://asia.nikkei.com/Politics/Company-in-focus-Malaysia-Airlines-losesanother-CEO-as-its-malaise-deepens', accessed at $15^{\text {th }}$ August 2018.

Zhang, P., Wierschem, D., Mediavilla, F. A., \& Hong, K. P. (2016) 'An Empirical Investigation on CEO Turnover in IT Firms and Firm Performance. Journal of International Technology and Information Management', Vol.25,No.2, pp. 67-82.

Zhang, Y. (2008) 'Information Asymmetry and the Dismissal of Newly Appointed CEOs: An Empirical Investigation. Strategic Management Journal', Vol.29, No. 8,pp. 859-872. 